\title{
Analysis of the State and Trends of Differentiation of Socio-Economic Development of Russian Regions
}

\author{
Elmira Amirova ${ }^{1},{ }^{*}$ Rabiyat Kutaeva ${ }^{2}$ \\ ${ }^{I}$ Institute of Socio-Economic Research of the Dagestan Federal Research Centre of the Russian Academy of Sciences, \\ Russia \\ ${ }^{2}$ Dagestan State University of National Economy, Russia \\ *Email: Emulya7@mail.ru
}

\begin{abstract}
In this article, the author examines various forms of socio-economic inequality and socio-economic development problems of the Russian Federation regions. The article compares the level of the Russian Federation's federal districts' main macroeconomic indicators in the context of three main groups that characterise investment product development and the standard of living of the population of the regions. For each of the macroeconomic groups of indicators, a rating of regions was derived, representing the level of interregional differentiation. The article suggests directions for improving the mechanism of levelling regional socio-economic differentiation, based on the principles of sustainability and balance and the observance of a dynamic balance of interests in the economic and social spheres. It is concluded that the large-scale and long-term lag in the socio-economic development of the subjects of the Russian Federation is associated with the regional economic and investment policy pursued by the federal authorities.
\end{abstract}

Keywords: Interregional differentiation, Evaluation indicators, Balanced development, Regulation of regional development.

\section{INTRODUCTION}

The current period of development of the Russian economy, characterised by its instability and the need to improve the management system at the regional level of the country, requires an objective assessment of the uneven development of spatial social and economic systems.

Significant interregional differentiation is one of the fundamental problems of regional development in Russia. And although "...Russian regions experienced some convergence in income in the last decade as poorer regions grew more quickly (controlling for other factors)" as noted by researchers Bussolo M. et al. in the report" Towards a New Social Contract", analysing the results of a World Bank study, they conclude that "Russia has the highest level of inequality among large, emerging economies such as Brazil, China, and India" [1].
Theorists and practitioners repeatedly discuss several features and adverse consequences of this phenomenon's strengthening.

According to several researchers, the deepening of socio-economic imbalances gradually forms deep structural and parametric contradictions and begins to slow down economic growth $[2,3]$.

In recent decades, Russia has developed a steady trend of polarisation of the socio-economic development level, sharp property stratification, and differentiation of the population's standard of living by regions. Despite the increase in the values of indicators of the standard of living of federal districts' population for the period after 2010 , there is a stable pattern of increasing their differentiation [4].

The lack of an effective mechanism and effective implementation of various programmes balanced development of territories has led to the fact that the differences in the levels of socio-economic development of regions of the Russian Federation not only reduced but 
also increased, which indicates inefficiency by the authorities of the state regional economic, investment and social policy $[5,6]$.

Choosing the right strategy for regulating regional development to reduce the negative consequences of interregional differentiation and subsequent balanced socio-economic development $[7,8]$.

Also, an essential tool for reducing differentiation is eliminating administrative barriers in interregional cooperation of Russian regions, especially those located in the geographical neighbourhood. Thus, several studies have revealed a strong correlation between foreign trade and economic growth in the regions of the North Caucasus Federal District and the Southern Federal District (Krasnodar Territory, Astrakhan, Volgograd, Rostov Regions, the Republic of Dagestan and the Karachay-Cherkess Republic) [9].

The economic space's inhomogeneity is a natural process, and interregional socio-economic differentiation can be traced in all countries. Still, the scale of this inequality and the consequences may differ significantly. In this regard, research in the methodology for assessing spatial economic systems' uneven development is essential.

\section{RESEARCH METHODOLOGY}

Our proposed analysis of the differentiation of socioeconomic development of Russian regions is based on the use of a methodology for assessing interregional differentiation, which consists of three groups of indicators, which, in turn, include a list of economic and social indicators and statistical data for 2018 (see fig. 1) [10].

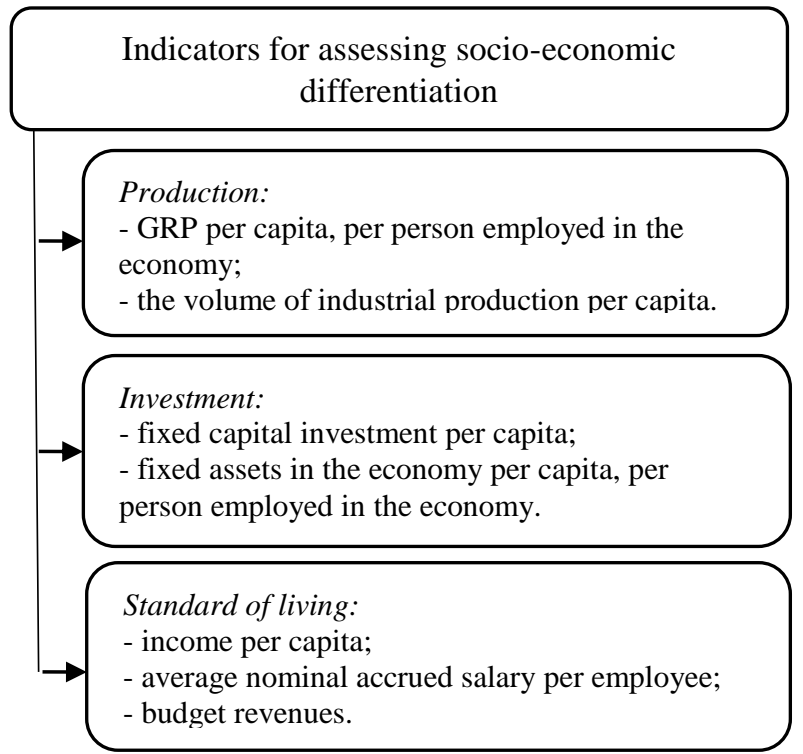

Figure 1 Methodology for assessing socio-economic differentiation.
Below we analyse the main macroeconomic indicators of the federal districts of the Russian Federation. For each of them, a rating is calculated that characterises the level of socio-economic differentiation of the Russian Federation's subjects.

\section{THE MAIN PART OF THE STUDY}

\subsection{Interregional differentiation in the sphere of production}

The gross regional product per capita characterises the trend of development of economic activity in the region and, in our opinion, is one of the main indicators of the level of development of the region. Despite the efforts made in recent years to improve the country's socio-economic situation, GRP production per capita in Russia is extremely uneven.

In terms of gross regional product per capita for an extended time, the leaders are the regions with special advantages - the Ural Federal District and the Central Federal District. Thus, on average in the federal districts of Russia, this indicator differs by 5 times. Of course, a powerful economic centre is the Ural Federal District, whose gross regional product per capita is $178.4 \%$. The lowest value of the indicator is in the underdeveloped North Caucasus and agrarian-industrial Southern Federal Districts $-34.1 \%$ and $61.4 \%$ of the gross regional product per capita, respectively. Despite the significant differences between the "rich" and "poor" subjects of the Russian Federation, they are still a minority, and a dense middle group dominates, which remains relatively stable. The most significant differentiation is in terms of gross regional product per person employed in the economy the value of the indicator for the North Caucasus Federal District is two and a half times less concerning the average Russian level and three times - to the Central Federal District, which characterises a low level of labour productivity (see table 1).

The situation in the industrial sector of the Russian regions is complicated. The level of industrial development in the regions can be described as low. Thus, in 2018, the volume of industrial production per capita in the North Caucasus Federal District was only $11.0 \%$ compared to the national average. The assessment of territorial differentiation in terms of industrial production per capita shows that concerning this indicator, there is an increase in values for individual territories, but as a result, the unevenness only increases (see table 1).

\subsection{Interregional differentiation in the field of investment}

Investment is an essential indicator of the development of production since investment determines the level, pace and prospects of development of both 
Table 1. Main indicators of differentiation in the sphere of production by federal districts of Russia, 2018 .

\begin{tabular}{|c|c|c|c|c|c|c|}
\hline \multirow[t]{2}{*}{ Region } & \multicolumn{4}{|c|}{$\overline{G R P}$} & \multicolumn{2}{|c|}{$\begin{array}{l}\text { Volume of industrial } \\
\text { production (types of } \\
\text { economic activity) }\end{array}$} \\
\hline & $\begin{array}{l}\text { Occupied } \\
\text { space }\end{array}$ & Per capita & $\begin{array}{l}\text { Occupied } \\
\text { space }\end{array}$ & $\begin{array}{l}\text { Per person } \\
\text { employed in } \\
\text { the economy }\end{array}$ & $\begin{array}{l}\text { Occupied } \\
\text { space }\end{array}$ & Per capita \\
\hline $\begin{array}{l}\text { Russian Federation - } \\
\text { total }\end{array}$ & $\ldots$ & 100 & $\ldots$ & 100 & $\ldots$ & 100 \\
\hline \multicolumn{7}{|l|}{ Federal districts: } \\
\hline Central & 2 & 129,2 & 2 & 120,9 & 3 & 91,0 \\
\hline North-West & 3 & 111,6 & 4 & 106,5 & 2 & 103,6 \\
\hline South & 7 & 61,4 & 7 & 64,3 & 7 & 45,2 \\
\hline North Caucasus & 8 & 34,1 & 8 & 39,7 & 8 & 11,0 \\
\hline Volga & 6 & 73,1 & 6 & 73,9 & 6 & 80,0 \\
\hline Ural & 1 & 178,4 & 1 & 179,5 & 1 & 192,7 \\
\hline Siberian & 5 & 83,7 & 5 & 88,0 & 4 & 85,5 \\
\hline Far Eastern & 4 & 109,6 & 3 & 109,7 & 5 & 80,0 \\
\hline
\end{tabular}

${ }^{*}$ Calculated based on regional statistics [11].

individual subjects of Russia and the country as a whole. The analysis of the current state of the investment component clearly demonstrates the significant differentiation of regional development. Per capita investment in fixed assets in the North Caucasus Federal District as a whole is more than two times lower than the average in Russia, and in some regions, it is 4 or more times lower (see table 2). Investments in fixed assets per

Table 2. Key indicators of differentiation in the field of investment by federal districts of Russia, 2018 .

\begin{tabular}{|c|c|c|c|c|c|c|}
\hline \multirow[t]{3}{*}{ Region } & \multirow{2}{*}{\multicolumn{2}{|c|}{$\begin{array}{l}\text { Fixed capital investment per } \\
\text { capita }\end{array}$}} & \multicolumn{4}{|c|}{ Fixed assets in the economy } \\
\hline & & & \multicolumn{2}{|c|}{ per capita } & \multicolumn{2}{|c|}{$\begin{array}{l}\text { per } 1 \text { employed in the } \\
\text { economy }\end{array}$} \\
\hline & $\begin{array}{l}\text { Occupied } \\
\text { space }\end{array}$ & $\begin{array}{l}\text { in \% of the } \\
\text { Russian } \\
\text { Federation }\end{array}$ & $\begin{array}{l}\text { Occupied } \\
\text { space }\end{array}$ & $\begin{array}{c}\text { in \% of } \\
\text { the } \\
\text { Russian } \\
\text { Federatio } \\
\text { n }\end{array}$ & $\begin{array}{l}\text { Occupied } \\
\text { space }\end{array}$ & $\begin{array}{l}\text { in \% of the } \\
\text { Russian } \\
\text { Federation }\end{array}$ \\
\hline Russian Federation - total & $\ldots$ & 100 & $\ldots$ & 100 & $\ldots$ & 100 \\
\hline \multicolumn{7}{|l|}{ Federal districts: } \\
\hline Central & 4 & 103,3 & 3 & 118,0 & 4 & 106,9 \\
\hline North-West & 3 & 124,9 & 4 & 117,8 & 3 & 113,7 \\
\hline South & 6 & 71,3 & 5 & 68,7 & 5 & 74,4 \\
\hline North Caucasus & 8 & 46,7 & 8 & 36,5 & 8 & 45,3 \\
\hline Volga & 7 & 69,9 & 6 & 68,4 & 6 & 72,0 \\
\hline Ural & 1 & 198,0 & 1 & 217,1 & 1 & 206,9 \\
\hline Siberian & 5 & 76,4 & 7 & 65,5 & 7 & 70,0 \\
\hline Far Eastern & 2 & 141,8 & 2 & 127,3 & 2 & 126,2 \\
\hline
\end{tabular}

*Calculated based on regional statistics [11]. 
capita over $100 \%$ have 4 federal districts, of which the highest value of the indicator in 2018 was in the Ural Federal District and the Far Eastern Federal District: $198.0 \%$ and $141.5 \%$, respectively.

The dangerous and unmanageable nature of Russia's investment process is evidenced by the enormous differences between the country's regions in terms of investment in the economy and human capital, the consequence of which is the same differentiation in terms of socio-economic development. This can be clearly seen when comparing fixed assets and investments per capita in federal districts representing Russia's large economic zones (see table 2). The capital-to-capital ratio of the population of four districts (Ural, Far Eastern, Central and North-Western) is higher than the national average (by 1.2-2.2 times) and, accordingly, they have a higher indicator of newly created value. The rest of the federal districts lag significantly behind the national average of capital-labour ratio. Moreover, it is quite obvious from the data in table 2 that this lag is determined by the limited availability of fixed assets, hence investment in the economy. Special attention should be paid to the fact that the gap in the population's capital-labour ratio, for example, in the Ural and North Caucasus Federal Districts, reaches 5.9 times and investment per capitaalmost 4 times. Moreover, the trend is that the asymmetry of federal districts increases significantly.

\subsection{Interregional differentiation of income of the population}

The uneven economic development of the regions, of course, affects the material well-being of the population, which leads to a significant differentiation of income, level and quality of life. The grouping of regions concerning the average per capita income to the average Russian level is similar to the grouping of production presented above

GRP per capita, the volume of industrial production per capita and other indicators. As of 2017, the average per capita income in the North Caucasus Federal District is $29.0 \%$ lower than the national average and $56.2 \%$ lower than in the Central Federal District (see table 3).

Salary occupies a special place in the structure of income of the population. The comparison of wage indicators of the Russian Federation regions as a whole reflects the unfavourable situation (see table 3 ). Low wages in most regions of the North Caucasus Federal District $(61.9 \%)$, the Southern Federal District (73.2\%) and the Volga Federal District $(73.2 \%)$ are mostly the result of insufficient labour productivity, and weak capital availability since the industry structure of costs (material, depreciation, payroll) is relatively stable.

Consequently, the low level of regional development is one of the reasons for the high level of subsidisation of regional budgets. As of 2018, most federal districts and

Table 3. The basic indicators of differentiation of incomes of the population by Federal districts of Russia, 2018.

\begin{tabular}{|c|c|c|c|c|c|c|}
\hline \multirow[t]{2}{*}{ Region } & \multicolumn{2}{|c|}{$\begin{array}{c}\text { Per capita cash } \\
\text { income (per month) }\end{array}$} & \multicolumn{2}{|c|}{$\begin{array}{l}\text { Average monthly } \\
\text { nominal salary. }\end{array}$} & \multicolumn{2}{|c|}{ Budget revenues } \\
\hline & $\begin{array}{l}\text { occupied } \\
\text { space }\end{array}$ & $\begin{array}{c}\text { in \% of } \\
\text { the } \\
\text { Russian } \\
\text { Federatio } \\
\text { n }\end{array}$ & $\begin{array}{l}\text { occupied } \\
\text { space }\end{array}$ & $\begin{array}{l}\text { in \% of the } \\
\text { Russian } \\
\text { Federation }\end{array}$ & Total & $\begin{array}{c}\text { Gratuitous } \\
\text { transfers, \% of } \\
\text { income }\end{array}$ \\
\hline $\begin{array}{l}\text { Russian Federation - } \\
\text { total }\end{array}$ & $\ldots$ & 100 & $\ldots$ & 100 & 100 & 17,5 \\
\hline \multicolumn{7}{|l|}{ Federal districts: } \\
\hline Central & 1 & 127,2 & 1 & 125,1 & 100 & 9,6 \\
\hline North-West & 3 & 106,1 & 3 & 114,0 & 100 & 14,8 \\
\hline South & 5 & 86,2 & 7 & 73,2 & 100 & 29,6 \\
\hline North Caucasus & 8 & 71,0 & 8 & 61,9 & 100 & 58,3 \\
\hline Volga & 6 & 81,3 & 6 & 73,2 & 100 & 17,6 \\
\hline Ural & 4 & 104,0 & 4 & 109,3 & 100 & 9,0 \\
\hline Siberian & 7 & 74,6 & 5 & 86,5 & 100 & 20,7 \\
\hline Far Eastern & 2 & 107,8 & 2 & 118,2 & 100 & 31,3 \\
\hline
\end{tabular}

${ }^{*}$ Calculated based on regional statistics [11]. 
Russian Federation subjects remain almost entirely dependent on the federal budget's gratuitous assistance. The amount of gratuitous receipts to the consolidated budgets of the Ural Federal District (9.0\%), the Central Federal District (9.6\%), the North-Western Federal District (14.8\%) and the Volga Federal District (17.6\%) can be considered acceptable, and for the rest of the federal districts, the values of this indicator exceed the national average. The most impressive is the level of budget subsidies in the North Caucasus Federal District. The share of gratuitous transfers from the federal budget to the North Caucasus Federal District subjects' regional budgets is $58.3 \%$, which significantly exceeds this indicator's value for other districts (see table 3).

\section{CONCLUSIONS}

The analysis shows that such a large-scale and longterm lag in the Russian Federation's subjects' socioeconomic development is associated with the federal authorities' regional economic and investment policy.

The experience of state regulation of regional development, as well as the study of the opinions of scientists on the validity of the use of the principle of state regional policy of polarised (focused) development, aimed at advancing the development of "locomotive" subjects of the Russian Federation, shows the inefficiency of the existing regional policy to equalise the level of socio-economic development of regions.

In this regard, the essential object of the federal regional policy of influencing interregional socioeconomic differentiation in Russia should be state support for problem regions of the country, that is, territories whose problems and tasks cannot be solved without direct or indirect participation of the state.

Reducing the unevenness of Russian regions' socioeconomic development, the transition of problem regions to long-term development is the main public administration task. The depth and causes of the problem situation are the basis for determining ways to bring problem regions out of the crisis, developing administrative measures and economic levers of regional management. This determines the target setting for using the evaluation results for state regulation of the economy.

We have identified the following measures to reduce the socio-economic differentiation of the subjects of the Russian Federation:

- creation and adoption of long-term programs for stable socio-economic development of regions, especially backward ones;

- effective use of the own resource potential of backward regions;
- using the format of a special economic regime for accelerated socio-economic development of problem regions.

\section{REFERENCES}

[1] M. Bussolo, M.E., V. Davalos Peragine, R. Sundaram, Toward a New Social Contract, Taking On Distributional Tensions in Europe and Central Asia, A Closer Look at Spatial Disparities in the Russian Federation. Retrieved from: https://openknowledge.worldbank.org/bitstream/ha ndle/10986/30393/9781464813535.pdf (date of request: 14.12 .2020 )

[2] P.A. Bulochnikov, K.B. Smirnov, Interregional differentiation of spatial development of regions of the Russian Federation, St. Petersburg Economic Journal 4 (2019) 68-75. DOI: https://doi.org/10.25631/PEJ.2019.4.68.75

[3] V.Yu. Maslikhina, Analysis of factors and conditions of interregional differentiation and their impact on the region's economic security, Innovative development of the economy 5-2(53) (2019) 185-196.

[4] N.A. Gerasimenko, The standard of living of the Russian population: features of interregional differentiation dynamics, University Bulletin 11 (2020) 181-188.

[5] M.A. Bagomedov, Institutional problems of development of interregional and intraregional differentiation of living standards and social sphere in labour-surplus and multiethnic regions of the North Caucasus Federal District, Issues of structuring the economy 3 (2013) 65-71.

[6] A.Sh. Akhmeduev, Problems of excessive polarisation of the level of socio-economic development of Russian regions and imperatives of modernisation of state regional policy, Regional problems of economic transformation 6 (2017) 37 51.

[7] V.S. Fedolyak, Interregional disproportions of socio-economic development through the prism of basic theories of the regional economy, Saratov University News, New series, The Economic Series, Management, Law, Vol. 19, Iss. 1, 2019. Retrieved

from: https://cyberleninka.ru/article/n/mezhregionalnyedisproportsii-sotsialnoekonomicheskogo-razvitiyaskvoz-prizmu-bazovyh-teoriy-regionalnoyekonomiki (date of request: 17.11.2020)

[8] A.A. Bashirova, Principles of sustainability and balance in the mechanism of regulation of socioeconomic development of the region, Bulletin of the 
Altai Academy of Economics and Law 9-2 (2020) 204-209. DOI: https://doi.org/10.17513/vaael.1322

[9] N.S. Gichiev, S.K. Kutaev, S. M. Gimbatov. Influence Of Foreign Trade On The Economics Of The North Caucasian Macroregion, European Publisher, 2020.2 DOI: https://doi.org/10.15405/epsbs.2020.10.05.236

[10] E.A. Amirova, Methodological approaches to assessing Russian regions' socio-economic differentiation, Regional Problems of Economic Transformation 1 (2020) 65-70. DOI: https://doi.org/10.26726/1812-7096-2020-01-65$\underline{70}$

[11] Regions of Russia: socio-economic indicators, 2018: stat. coll. Rosstat, Moscow, 2019. 